\title{
Physico-mechanical Properties of Basalt-based Brake Pad as Alternative to Ceramics Brake pad
}

\author{
Gai Peter Friday ${ }^{1 *}$, Adisa, Ademola Bello ${ }^{2}$, Aje, $_{\text {Tokan }}^{3}$, Bawa, Mohammed A ${ }^{4}$ \\ ${ }^{1}$ Uac Foods Nigeria Limited, Km 16 Ikorodu Road Ojota Lagos Nigeria \\ ${ }^{2,3,4}$ Department of Mechanical/Production Engineering Faculty of Engineering and Engineering Technology, Abubakar Tafawa Balewa \\ University Bauchi, Nigeria
}

\author{
DOI: $10.36348 /$ sjet.2022.v07i01.003 $\quad$ | Received: 30.11.2021 | Accepted: 01.01.2022 | Published: 15.01 .2022 \\ *Corresponding author: Gai Peter Friday \\ Uac Foods Nigeria Limited, Km 16 Ikorodu Road Ojota Lagos Nigeria
}

\section{Abstract}

A basalt-based automobile brake pad was developed through optimization of the volume fractions and manufacturing parameters, a mathematical model was developed based on rule of mixture for the optimization of the volume fraction and the solution obtained using excel solver is as follow; basalt $38 \%$, cast iron chips $26 \%$, bronze $12 \%$, glass fibre $12 \%$ and phenolic resin $12 \%$. The manufacturing parameters were design using full factorial design of three levels and three factors, twenty-seven runs were obtained from the design, consequently twenty-seven samples were produced by compression moulding. The constituent materials were properly mixed to obtained homogeneous mixture and compressed into a mould with a cavity similar to the shape of the friction pad this was done at different moulding pressures of $30 \mathrm{MPa}, 27 \mathrm{MPa}$ and $24 \mathrm{MPa}$, the curing temperatures were $180^{\circ} \mathrm{C}, 200^{\circ} \mathrm{C}$ and $220^{\circ} \mathrm{C}$ and the curing of 5 minutes, 10 minutes and 15 minutes as obtained from the factorial design. The samples produced were subjected to tests, the results showed that the basalt brake pad has the following properties; compressive strength of $137 \mathrm{mPa}$, coefficient of friction 0.476 , hardness $70 \mathrm{HRB}$, density of $2768 \mathrm{~kg} / \mathrm{m}^{3}$ thermal conductivity of $0.66 \mathrm{~W} / \mathrm{mK}$, water absorption of $0.377 \%$, oil absorption of $0.25 \%$, void content of $18.93 \%$, wear rate of $9.0 \times 10^{-4} \mathrm{~g} / \mathrm{m}$ and the TGA result shows that the basaltbased brake pad is thermally stable up to a temperature of $500^{\circ} \mathrm{C}$. The properties of the basalt-based brake pad are within the acceptable range and can satisfactorily substitute basalt.

Keywords: Physico-mechanical, Properties, Basalt, Brake pad, Alternative, Ceramics.

Copyright (C) 2022 The Author(s): This is an open-access article distributed under the terms of the Creative Commons Attribution 4.0 International License (CC BY-NC 4.0) which permits unrestricted use, distribution, and reproduction in any medium for non-commercial use provided the original author and source are credited.

\subsection{INTRODUCTION}

Brake pad is one of the essential components of a braking system; the brake pad has the friction surface which provides the braking power of a braking system.

Two brake pads are required in each wheel of a car, when the brake is applied fluid with sufficient pressure from the brake master cylinder via the connection pipe move to the wheels' brake ports and forces the pistons in the brake ports outwards this in turn presses the friction surfaces of the brake pads against the rotating brake disc thereby retarding the speed of the moving car until it comes to rest. This involved converting the kinetic energy of a moving car into heat energy and the heat is dissipated at the wheels of the car, because of the condition of it services brake pad is a complex component that cannot be produced from a single material hence it is composite material which involve combination of two or more materials for the production in order to achieved the desire properties of the brake pad, these properties are good frictional surface at low and high temperature, low noise, prolong life, increase strength and rigidity as well low porosity.

The changes in the weight percentage or types of elements in the formulation may result to the alteration of the chemical, mechanical and physical properties of the brake pad materials developed (Jang et al., 2004; Cho et al., 2005 and Mutlu et al., 2005; Zaharudin et al., 2012). 
Gai Peter Friday et al.,; Saudi J Eng Technol, Jan, 2022; 7(1): 16-33

History records the use of many kinds of materials for brakes ('friction materials'). For example, wagon brakes used wood and leather. In fact, many current brake materials still contain organic-based materials, like polymers and plant fibers. Emerging railroad technology in the1800's required brake materials to perform under high loads and speeds. Friction experiments were conducted with iron brake shoes in the 1870's (Blau, 2000).

The discovering of asbestos as a material for brake linings and pad gave birth to modern material for brake pad and lining. However, Many years ago brake pads were made from different materials ranging from cotton, asbestos iron etc (Blau, 2000).

The birth of modern brake pad was dated 1910 when Herbert Frood of England discovered asbestos as friction material for brake linings and pad. The material gains wide acceptance because of ability to withstand high temperature an excellent insulator.

In 1970s the National Safety Council report that the asbestos use in brake pads has harmful potential (Castrop, 1948). McDonald et al., (1970), in their work report that Mesothelioma among brake mechanics which is responsible for carcer.

Stanton and Wrench (1972) found that the fibres of asbestos are more carcinogenic, but could not identify a precise fiber length that did not demonstrate biological activity.

This discovery caused a banned on the use of asbestos in brake industries as a result an intensive researched for alternative materials begun by different researchers as stated below.

Ibhahode and Dagwa (2008), developed an asbestos-free brake pad material using Palm Kernel shell (PKS) as base materials, other materials used in the production of the composite material are Cashew nutshell liquid, carbon black, iron ore, brass chips, ceramics, Sulphur, quartz and calcium carbonate.

Ikpambese et al. (2014), evaluated the performance of palm kernel fibre as a friction material for brake pad, other materials used in the composite of the brake pad are epoxy resin, aluminum oxide, graphite and calcium carbonate

Ibrahim et al. (2017) also produced a brake pad from Palm Kernel Shell, phenolic resin, Aluminium oxides, Graphite and Calcium carbonate in a ratio of $40 \%, 50 \%, 3 \%, 3 \%, 4 \%$ respectively. The result shows the brake pad has friction coefficient of 0.39 , water absorption of $4 \%$, abrasive resistance of $97 \%$, swelling thickness of $1 \%$.
Onyeneke et al. (2014) similarly produced brake pad using periwinkle, coconut shell, araldite and epoxy, arbon, aluminum, copper and zinc. Test result show the brake pad has a bonding strength of $2.5 \mathrm{MPa}-$ $2.7 \mathrm{MPa}$, friction coefficient of $0.4-0.6$ and Vickers hardness of $80-85$. Other parameters were not determined.

Lawal et al. 2017 produced an asbestos free brake pad using saw dust of difference sieve size of $100 \mu \mathrm{m}, 355 \mu \mathrm{m}, 710 \mu \mathrm{m}$ as base material of $55 \%$, steel dust $15 \%$, graphite $5 \%$, silicon carbide $10 \%$ and epoxy resin $15 \%$ using compression moulding method. Hardness, compressive strength, density, ash content, wears rate and water absorption were examined the result obtained reveal the finer sieve size has better properties.

Mutlu et al. (2015) studied the effect of porosity in friction performance of brake pad using waste tire dust (WTD), other materials used in the production of the brake pad are phenolic resin, copper particles, $\mathrm{Al}_{2} \mathrm{O}_{3}$ graphite, brass particles, cashew and barite. The volume fraction of the waste tire dust was varied from $5 \%-15 \%$ while the volumes fraction of other materials was maintained constant.

Amaren et al. (2013), investigated the the effect of particle size on the wear behaviour brake pad produced from periwinkle as a base material. Pin on disc was used to perform the wear test under different test conditions such as periwinkle particle size, sliding speed, applied load and temperature. The results of the study showed that wear rate increase with increasing particle size of the periwinkle, sliding speed and temperature.

Balaji and Kalaichelvan (2012), deployed the use of Golden ratio optimization tool to investigate the wear characteristics of non-asbestos semi-metallic brake pad material. Materials selected are shown in table 3 . The golden ratio optimization tool generated 18 sets of composition. Therefore, 18 samples were produced.

Nwigbo and Asogwa (2016) Evaluate the performance of rice husk and palm kernel shell powder as a material for brake pad, other materials included are silica, calcium carbonate, powder graphite and epoxy resin were used to formed the composite material for the brake pad.

The result shows that the hardness of the brake pad specimens range from $238 \mathrm{BH}$ and $205.3 \mathrm{BH}$, the highest hardness has a composition of $23 \mathrm{~g}$ of palm kernel shell, $40 \mathrm{~g}$ of rice husk, $5 \mathrm{~g}$ of silica, $5 \mathrm{~g}$ of calcium carbonate and $22 \mathrm{~g}$ of graphite.

The water absorption decreased as weight ratio of rice husk, epoxy and palm kernel increase. The TGA 
Gai Peter Friday et al.,; Saudi J Eng Technol, Jan, 2022; 7(1): 16-33

shows the material has a thermal stability of up to $600^{\circ} \mathrm{C}$ before degradation of the material commenced.

The coefficient of friction of the material ranges between 0.3 to 0.39 , the percentage wear loss is between $0.4 \%$ to $4.5 \%$ at a speed range of $60 \mathrm{~km} / \mathrm{hr}$ to $250 \mathrm{~km} / \mathrm{hr}$. the $\%$ wear increased as the speed increased.

Adeyemi et al. (2016), investigated the use of ternary Agro-waste as filler in brake pad material. The ternary Agro-waste was an intermixed of (Cocoa Beans Shell CBS, Maize Husk MH and Palm Kernel Shell PKS). These materials were combined with other materials as shown in table 4 to form the composite of the brake pad materials.

The result shows that the coefficient of friction in increased with increased in filler (Palm Kernel Shell, Maize husk and Cocoa beans shell).

The wear rate decreased as epoxy resin content increased in the formulation this is attributed to increase in the interfacial bonding between the materials particles.

It is noted that the water absorption of the composite material decreased as the filler (PKS, MK and CBS) content decreased. The result shows that the tensile strength decreased as the filler content with increased in filler content.

The result also revealed that the compressive strength increased with increase in epoxy content. Idris et al. (2013), explored the use of banana peel as friction material for brake pad, phenolic resin was used as a binder and varied from $5-30 \%$ of weight at an interval of 5 .

The banana peel was dried and pulverized to a fine powder the experiment was conducted with carbonized and uncarbonized banana peel powder.

The result shows that the compressive strength, hardness and specific gravity increased with increase in binder while water soak, oil soak, wear rate and percentage charred decrease with increase in wt $\%$ of binder.

Coefficient of friction of the material also increased with increase in weight percentage of the resin, in all the result shows that $25 \%$ of uncarbonized and $30 \%$ of carbonized of the banana peel has the best result.

Aigbodion et al. (2010), conducted a study using bagasse to produce brake pads in the ratio of $30 \%$ resin and $70 \%$ bagasse using compression moulding machine. The bagasses used in the study were sieve into grades of $100,150,250,350$ and $710 \mu \mathrm{m}$. The binder used during the study was phenolic resin (phenol formaldehyde). During the experiment, the compression moulding machine was set to a moulding temperature of $140^{\circ} \mathrm{C}$, moulding pressure of $100 \mathrm{KN} / \mathrm{cm} 2$ pressure and a curing time of 2 minutes and the final product was cured in an oven for 8 hours. The optimal values of the properties examined during the study include hardness (92 at $3000 \mathrm{kgf}$ ), density (1.65 g/cm3), microstructure analysis, compressive strength (103.5 MPa), flame resistance (charred with $46 \%$ ash), water and oil absorption (5.04 and $0.44 \%$ ).

Ruzaidi et al. (2011) carried out a study to produce a non- asbestos brake pad at varying composition of palm ash and polychlorinated biphenyls (PCB) waste along with thermoset resin as a binder and metal filler as abrasive. In their study five samples were produced using compressive, the moulding pressure, moulding temperature and curing time of $122 \mathrm{MPa}$, $150^{\circ} \mathrm{C}$ and 5 minutes respectively and were tested to examine its water absorption rate, morphological properties, wear rate and compression strength. The test results showed that the brake pads with higher percentage of palm ash gave the best mechanical and wears properties. This indicates that the wear properties of the produced brake pads are comparable with conventional brake pad. The study also concluded that brake pads can be developed by replacing asbestos with other reinforcement materials such as palm ash and PCB waste which could lower the cost of producing brake pad. It was also opined that compressive strength of the product can be increased if the percentage of palm ash in the composition is also increased while the samples with higher palm ash content may give optimum wear properties and water absorption rate which will lead to better properties of brake pad application.

Brake pads are classified in to three groups which are Semi-metallic, Organic and Ceramics with each having it disadvantages and advantages, among these ceramics brake pad has better performance it is quite in operations, less wear and long life. Its drawback is that it is expensive because of the processes involve in production which require specializes equipment (Krenkel and Langhaf 2014). It is on this backdrop that this research is working on basalt and other constituent materials as alternative to ceramics. Basalt is available in almost all countries most especially in Nigeria.

Basalt originates from volcanic magma and flood volcanoes, a very hot fluid or semifluid material under the earth's crust, solidified in the open air. Basalt is a common term used for a variety of volcanic rocks, which are gray, dark in colour, formed from the molten lava after solidification (Artemenko and Kadykova, 2008).

Basalt is well known as rock found in virtually every country around the world. Its main use is as a 
Gai Peter Friday et al.,; Saudi J Eng Technol, Jan, 2022; 7(1): 16-33

crushed rock used in construction, industrial and highway engineering. However, it is not commonly known that basalt can be used in manufacturing and made into fine, superfine and ultra-fine fibres. Is a single- ingredient raw material melt. Basalt rock is found in Plateau, Yobe and Adamawa States of Nigeria (Obiefuna and Nggada, 2014).
A typical photograph of basalt rock is shown in plate 1 and XRF was conducted to determine the chemical composition and compare with that of ceramic it was determined at Nigeria Institute Mining and Geoscience Tudun Jos Plateau Nigeria is showed in table 1 .

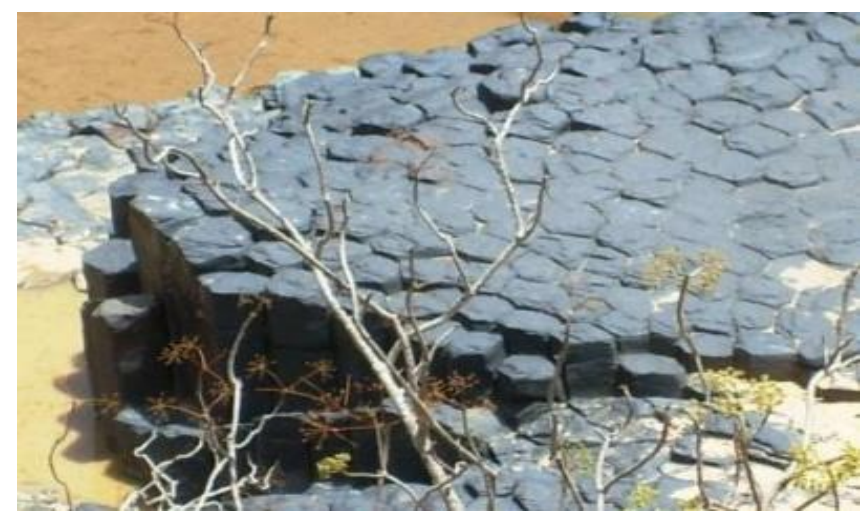

Plate-1: Basalt rock in Bachit, Riyom LGA Plateau State Nigeria.

Table-1: Chemical Composition Basalt Rock and ceramics

\begin{tabular}{|l|l|l|}
\hline Compound & $\begin{array}{l}\text { \% Composition in } \\
\text { Basalt }\end{array}$ & $\begin{array}{l}\text { \% Composition in } \\
\text { Ceramics }\end{array}$ \\
\hline $\mathrm{SiO}_{2}$ & 52.8 & 67.35 \\
\hline $\mathrm{Al}_{2} \mathrm{O}_{3}$ & 17.5 & 19.79 \\
\hline $\mathrm{Fe}_{2} \mathrm{O}_{3}$ & 10.3 & 2.52 \\
\hline $\mathrm{TiO}_{2}$ & 1.38 & 0.92 \\
\hline $\mathrm{CaO}$ & 8.59 & 2.32 \\
\hline $\mathrm{MgO}$ & 4.63 & 2.0 \\
\hline $\mathrm{Na}_{2} \mathrm{O}$ & 3.34 & 0.15 \\
\hline $\mathrm{K}_{2} \mathrm{O}$ & 1.46 & 4.13 \\
\hline $\mathrm{LOI}$ & 8.52 & \\
\hline
\end{tabular}

Basalt Rock fibres have no toxic reaction with air or water, are non-combustible and explosion proof. When in contact with other chemicals they produce no chemical reactions that may damage health or the environment. It has good hardness and thermal properties, can have various application as construction materials. Basalt is a major replacement to the asbestos, which poses health hazards by damaging respiratory systems. Basalt base composites can replace steel $(1 \mathrm{~kg}$ of basalt reinforces equals $9.6 \mathrm{~kg}$ of steel) as light weight concrete can be get from basalt fiber. (Kunal, 2012, http://basaltfm.com/eng/index/html; dt $12 / 10 / 2010)$.
As it is made of basalt rock is cheap and has several excellent properties (good mechanical strength, excellent sound and thermal insulator, non-flammable, biologically stable, etc. (Saravanan, 2006).

\section{MATERIALS AND METHODS}

The materials were carefully selected to give the desire service requirement of the composite material. These materials are basalt rock obtained from Bachit District in Riyom Local Government Area of Plateau State, glass fibre, bronze and cast-iron chips gotten as a waste from machine shop. Table 2 shows the functions of the selected materials in the composite.

Table-2: Materials Selected and Their Functions

\begin{tabular}{|l|l|l|}
\hline S/N & Material & Function \\
\hline 1 & Basalt powder & Filler \& friction dust \\
\hline 2 & Bronze chips & Improve thermal conductivity \\
\hline 3 & Cast iron chip & Service as lubricate because of graphite \\
\hline 4 & Fibre glass & Improve mechanical strength \\
\hline 5 & Phenolic resin & Binder (matrix) \\
\hline
\end{tabular}

\section{Materials Preparation}


Gai Peter Friday et al.,; Saudi J Eng Technol, Jan, 2022; 7(1): 16-33

In order to have homogeneous mixture the materials were grinded to fine particle and 150micro sieve was used in sieving the materials. Grinding material to a finer powder enables it to be homogeneously mixed and when it is properly bonded the material behave isotopically. Photographs of selected materials plate 2 . A linear optimization mo.

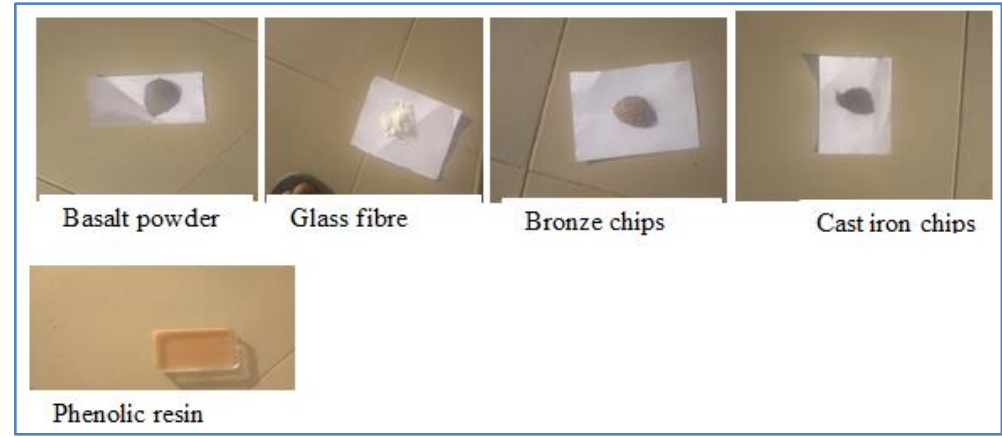

Plate-2: Photographs of Selected Materials

\section{METHODS}

Optimization model was developed based on the rule of mixture and the following assumptions were made:

1. There is a perfect binder between the particulates

2. The void content is less than $1 \%$

3. The particulates are equidistance hence the material is isotropy (Matthew and Rawlings, 2005).

Thus, the model is:

$\max f(\mu)=\sum_{j=1}^{5} \mathrm{c}_{\mathrm{j}} v_{j}$

Subject to:

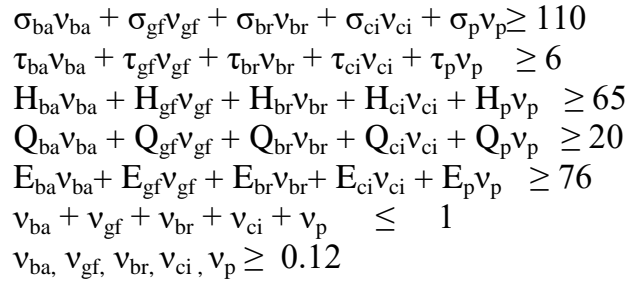

Where:

The subscripts

ba $=$ Basalt

gf = glass fibre

$\mathrm{br}=$ bronze

$\mathrm{ci}=$ cast iron chips

$\mathrm{p}=$ phenolic

$v=$ Volume fraction

$\sigma=$ compressive strength of material

$\mathrm{E}=$ Young modulus

$\mathrm{H}=$ Hardness of material

$\mathrm{Q}=$ Thermal conductivity of material

$\mu=$ Friction coefficient of material

$\tau=$ Shear strength of material

Constraint $1=$ compressive strength

Constraint $2=$ Shear strength

Constraint 3 = Hardness
Subject to:

$\sum_{j=1}^{5} \mathrm{a}_{\mathrm{ij}} v_{j} \geq b_{i} \forall_{i} 1 \ldots 5$

This is express as:

Maximize $\mathrm{f}(\mu)=\mu_{\mathrm{ba}} v_{\mathrm{ba}}+\mu_{\mathrm{gf}} v_{\mathrm{gf}}+\mu_{\mathrm{br}} v_{\mathrm{br}}+\mu_{\mathrm{ci}} v_{\mathrm{ci}}+\mu_{\mathrm{p}} v_{\mathrm{p}}$ .... Objective function

Objective is to maximize coefficient of friction

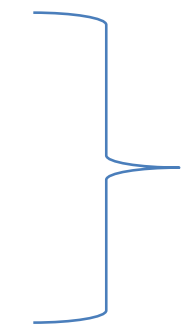

Constraint

Constraint $4=$ Thermal conductivity

Constraint $5=$ Modulus of elasticity

Constraint $6=$ sum of the volume fraction

The coefficients of the volume fractions as obtained from the table of properties of the selected materials were substituted in the equations and the equation below was formed.

Maximize $f(v)=0.7 v_{B}+0.5 v_{g}+0.22 v_{b}+0.4 v_{c}+0.15 v_{p}$

Subject to:

$$
\begin{aligned}
& 226 v_{\mathrm{B}}+1080 v_{\mathrm{g}}+315 v_{\mathrm{b}}+340 v_{\mathrm{c}}+45 v_{\mathrm{p}} \geq 110 \\
& 66 v_{\mathrm{B}}+1722 v_{\mathrm{g}}+303 v_{\mathrm{b}}+570 v_{\mathrm{c}}+48 v_{\mathrm{p}} \geq 6 \\
& 74 v_{\mathrm{B}}+74 v_{\mathrm{g}}+65 v_{\mathrm{b}}+65 v_{\mathrm{c}}+48 v_{\mathrm{p}} \geq 65 \\
& 1.5 v_{\mathrm{B}}+0.005 v_{\mathrm{g}}+63 v_{\mathrm{b}}+46 v_{\mathrm{c}}+0.25 v_{\mathrm{p}} \geq 20 \\
& 78 v_{\mathrm{B}}+73 v_{\mathrm{g}}+100 v_{\mathrm{b}}+180 v_{\mathrm{c}}+3.8 v_{\mathrm{p}} \geq 76
\end{aligned}
$$


Gai Peter Friday et al.,; Saudi J Eng Technol, Jan, 2022; 7(1): 16-33

$v_{\mathrm{ba}}+v_{\mathrm{gf}}+v_{\mathrm{br}}+v_{\mathrm{ci}}+v_{\mathrm{p}} \leq=1$

$v_{\mathrm{ba}}, v_{\mathrm{gf}}, v_{\mathrm{br},} v_{\mathrm{ci}}, v_{\mathrm{p}} \geq 0.12$.

After developing the optimization model, an excel solver optimization tool was used to obtain the optimum composition of the selected constituents' materials that will gives the optimum desire properties of brake pad. The compositions in volume fractions are basalt $38 \%$, glass fibre $12 \%$, bronze chips $12 \%$, cast iron chips $26 \%$ and phenolic resin $12 \%$. The result of the optimization obtained from the excel solver is shown in tables 3 and 4.

Table-3: Solution of Objection Function and Volume Fractions

\begin{tabular}{|l|l|l|l|l|}
\hline \multicolumn{2}{|l|}{ Cell } & Name & Original Value & \multicolumn{1}{c|}{ Friction coefficient } \\
\hline \$D\$6 & $\max (\mathrm{f} \mu)$ vba & 0 & 0.476196494 \\
\hline & Cell & Name & Original Value & Volume Fracrion \\
\hline & \$D \$5 & solution vba & 0 & 0.382788315 \\
\hline & \$E\$5 & solution vgf & 0 & 0.12 \\
\hline & \$F\$5 & solution vbr & 0 & 0.12 \\
\hline & \$G\$5 & solution vci & 0 & 0.257211685 \\
\hline & \$H\$5 & solution vp & 0 & 0.12 \\
\hline
\end{tabular}

Table-4: solutions of Constraints

\begin{tabular}{|c|c|c|c|c|c|}
\hline Cell & Name & Cell Value & Formula & Status & Slack \\
\hline \$D\$17 & Constraint 1 LHS & 421.2323524 & $\$ D \$ 17>=\$ E \$ 17$ & Not Binding & 311.2323524 \\
\hline \$D\$18 & Constraint 2 LHS & 318.0254022 & $\$ D \$ 18>=\$ E \$ 18$ & Not Binding & 312.0254022 \\
\hline \$D\$19 & Constraint 3 LHS & 67.48509483 & $\$ D \$ 19>=\$ E \$ 19$ & Not Binding & 2.485094831 \\
\hline \$D\$20 & Constraint 4 LHS & 20 & $\$ D \$ 20>=\$ E \$ 20$ & Binding & 0 \\
\hline \$D\$21 & Constraint 5 LHS & 97.37159191 & $\$ D \$ 21>=\$ E \$ 21$ & Not Binding & 21.37159191 \\
\hline \$D\$22 & Constraint 6 LHS & 1 & $\$ D \$ 22=\$ E \$ 22$ & Not Binding & 0 \\
\hline \$D\$5 & solution vba & 0.382788315 & $\$ D \$ 5>=0.12$ & Not Binding & 0.262788315 \\
\hline$\$ E \$ 5$ & solution vgf & 0.12 & $\$ E \$ 5>=0.12$ & Binding & 0 \\
\hline$\$ F \$ 5$ & solution vbr & 0.12 & $\$ F \$ 5>=0.12$ & Binding & 0 \\
\hline$\$ G \$ 5$ & solution vci & 0.257211685 & $\$ G \$ 5>=0.12$ & Not Binding & 0.137211685 \\
\hline$\$ \mathrm{H} \$ 5$ & solution vp & 0.12 & $\$ H \$ 5>=0.12$ & Binding & 0 \\
\hline
\end{tabular}

\section{Optimization of Manufacturing Parameters Using Design of Experiment}

Apart from the volume fraction influence on the properties of brake pad, manufacturing parameters also have significant control on the properties of brake pad.

It is on this premise, the work looked at the under listed manufacturing parameters which have influence on the properties of brake pad, these parameters are:

1. Moulding pressure.

2. Heat treatment temperature.

3. Heat treatment time.

Design of Experiment (DOE) was used to generate different set of manufacturing parameters. Full factorial design was run on MINITAB 18 software which generates these set of manufacturing parameters.

These sets of different conditions generated as shown in table 2 were used to produce twenty-seven samples.
These three manufacturing parameters are (moulding pressure, heat treatment temperature and heat treatment time) which are the factors have minimum, medium, and high levels.

In this case the factorial design will take the form $(\mathrm{L})^{\mathrm{N}}$.

Where $\mathrm{L}=$ level and $\mathrm{N}=$ factors

For this design $\mathrm{N}$ represents the manufacturing parameters which are three (3)

Therefore, the number of runs $=3 \times 3 \times 3=27$

Kim and Jang (2003) used the Taguchi's method to optimize the manufacturing parameters of brake pad and it was found that the best parameters are moulding pressure $27 \mathrm{MPa}$, heat treatment temperature $200^{\circ} \mathrm{C}$ and heat treatment time six hours.

Based on this the research assumed the following levels in table 5 to produce the brake pad.

Table-5: Manufacturing parameters level

\begin{tabular}{|l|l|l|l|l|}
\hline S/N & Level & Moulding Pressure (MPa) & Heat Treatment Temperature $\left({ }^{\mathbf{0}} \mathbf{C}\right)$ & Heat Treatment time $(\mathrm{mins})$ \\
\hline 1 & low & 24 & 180 & 5 \\
\hline 2 & Medium & 27 & 200 & 10 \\
\hline
\end{tabular}




\begin{tabular}{|l|l|l|l|}
\hline \hline 3 & High & 30 & 220 \\
\hline
\end{tabular}
15

These low, medium and high levels are input in the DOE design which uses the Minitab software to give the factorial design as shown in table 6 .

Table-6: Factorial Design Manufacturing Parameters Using Design of Experiment Minitab 18

\begin{tabular}{|l|l|l|l|l|l|l|}
\hline StdOrder & RunOrder & PtType & Blocks & Mp & Cte & Cti \\
\hline 8 & 1 & 1 & 1 & 24 & 220 & 10 \\
\hline 6 & 2 & 1 & 1 & 24 & 200 & 15 \\
\hline 25 & 3 & 1 & 1 & 30 & 220 & 5 \\
\hline 7 & 4 & 1 & 1 & 24 & 220 & 5 \\
\hline 1 & 5 & 1 & 1 & 24 & 180 & 5 \\
\hline 11 & 6 & 1 & 1 & 27 & 180 & 10 \\
\hline 24 & 7 & 1 & 1 & 30 & 200 & 15 \\
\hline 12 & 8 & 1 & 1 & 27 & 180 & 15 \\
\hline 16 & 9 & 1 & 1 & 27 & 220 & 5 \\
\hline 4 & 10 & 1 & 1 & 24 & 200 & 5 \\
\hline 26 & 11 & 1 & 1 & 30 & 220 & 10 \\
\hline 20 & 12 & 1 & 1 & 30 & 180 & 10 \\
\hline 21 & 13 & 1 & 1 & 30 & 180 & 15 \\
\hline 15 & 14 & 1 & 1 & 27 & 200 & 15 \\
\hline 27 & 15 & 1 & 1 & 30 & 220 & 15 \\
\hline 3 & 16 & 1 & 1 & 24 & 180 & 15 \\
\hline 2 & 17 & 1 & 1 & 24 & 180 & 10 \\
\hline 9 & 18 & 1 & 1 & 24 & 220 & 15 \\
\hline 13 & 19 & 1 & 1 & 27 & 200 & 5 \\
\hline 10 & 20 & 1 & 1 & 27 & 180 & 5 \\
\hline 22 & 21 & 1 & 1 & 30 & 200 & 5 \\
\hline 23 & 22 & 1 & 1 & 30 & 200 & 10 \\
\hline 19 & 23 & 1 & 1 & 30 & 180 & 5 \\
\hline 5 & 24 & 1 & 1 & 24 & 200 & 10 \\
\hline 17 & 25 & 1 & 1 & 27 & 220 & 10 \\
\hline 18 & 26 & 1 & 1 & 27 & 220 & 15 \\
\hline 14 & 27 & 1 & 1 & 27 & 200 & 10 \\
\hline & & & & & & \\
\hline
\end{tabular}

\section{Production of Samples}

A cylindrical mould of diameter $20 \mathrm{~mm}$ and $8 \mathrm{~mm}$ height was constructed for the production of the samples. The mould was properly cleaned and constitutes materials that form the samples were weighed/ measured based on the volume fraction of each constituent as obtained from the optimization model. The mixture of these materials was properly mixed using a two arm-stirrer at a speed of $250 \mathrm{rev} / \mathrm{min}$ for 20 minutes to form homogeneous mixture before pouring the mixture into the mould after the mould was waxed with Vaseline; this is to enable easy removal of the samples from the mould.

The mixture poured into the mould is compressed at different pressure of $24 \mathrm{MPa}, 27 \mathrm{MPa}$ and 30MPa using hydraulic press.

After compressing the mixture, the samples were ejected from the mould and cured in an oven at different curing temperatures and curing time based on the design parameters obtained from the Design of
Experiment (DoE) as shown in DoE table 5. Some samples produced are shown in plate 3 .

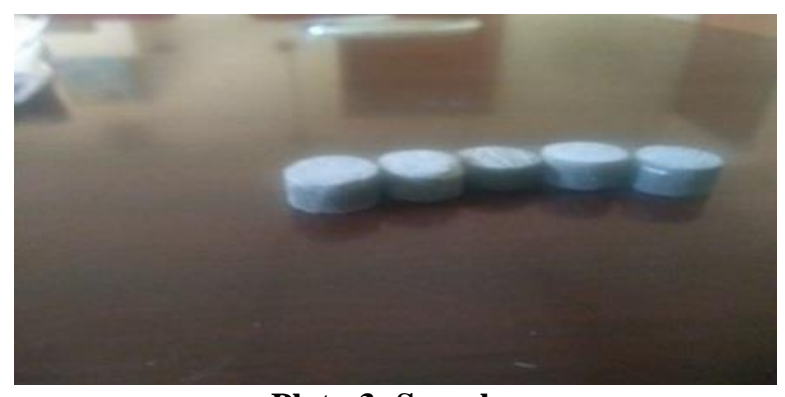

Plate-3: Samples

Production of brake pad

The mould to produce the pad was first fabricated according to the dimensions of the brake pad. The back plate was placed into the mould and position by the locators in the mould, the constitutes materials for the brake pad were properly mixed to form homogeneous mixture before pouring the mixture into the mould before pouring the internal walls of mould 
was waxed with neutral shoe polish, this is to enable easy removal of the brake pad from the mould. 26 The mixture poured into the mould is compressed at different pressure of $24 \mathrm{MPa}, 27 \mathrm{MPa}$ and $30 \mathrm{MPa}$ using hydraulic press. After compressing the mixture, the brake pads were ejected from the mould and cure in an oven at different curing temperatures and curing time based on the manufacturing parameter obtained from the DOE as shown in DoE table 6. Samples of the brake pad produced are showed in plate 4 and 5 while the mould is showed in plate 6 .

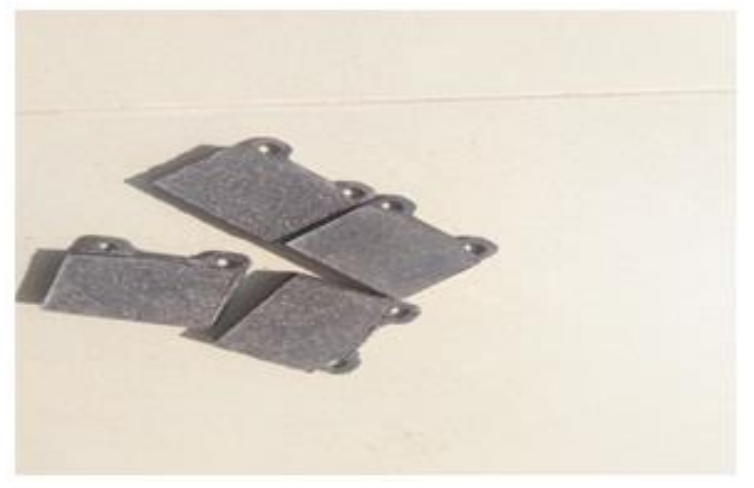

Plate-4: Mercedes Benz 200 Brake pad

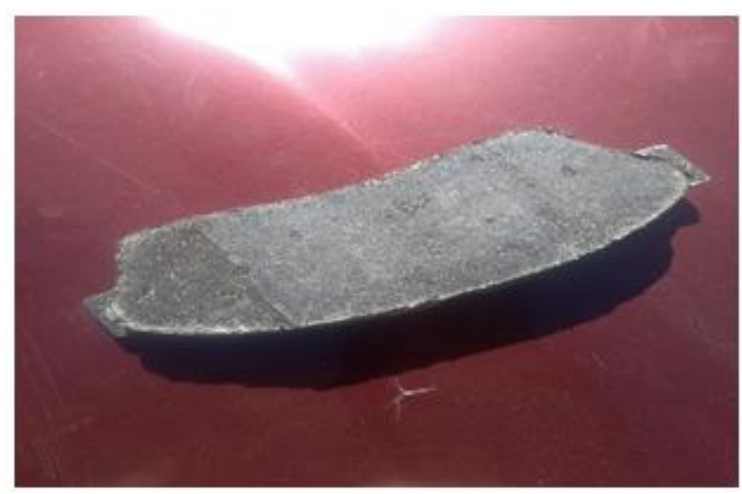

Plate-5: Toyota Camry 1998 Brake pad

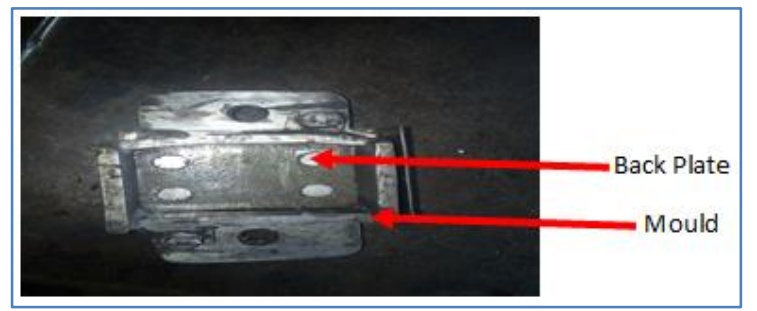

Plate-6a: Mould of Mercedes Benz 200

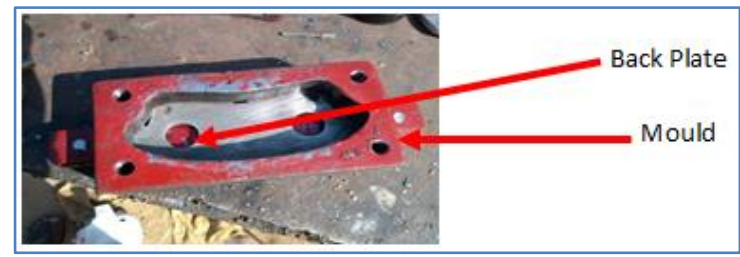

Plate-6b: Mould of Toyota Camry 1998

Various tests were carried out on the samples produced and the test result is summarized in table 7 .

\section{Determination of Coefficient of Friction}

The coefficient of friction test was conducted according ASTM G99 and DIN 50324.Twenty-seven samples of $20 \mathrm{~mm}$ diameter and $8 \mathrm{~mm}$ height were produced and the test carried out using an Anton Paar pin-on-disk Tribometer on a load of $8 \mathrm{~N}$ at sliding velocity of $10 \mathrm{~cm} / \mathrm{s}$ for a distance of $50 \mathrm{~m}$.

CoF is mathematical express as: CoF. $=\frac{\text { Frictional force }}{\text { Normal Reaction }}=\frac{F r}{R}$

Where: $\mathrm{Fr}=$ frictional force, $\mathrm{R}=$ normal reaction.

\section{Determination of Compressive Strength}

The compressive strength test was conducted according to ASTM D3410 on a SM 1000 Universal Testing Machine. The twenty- seven samples produced were subjected to this test and result is showed in table 7. The compressive strength is expressed as the maximum compressive load the material withstands per unit area; the load must be perpendicular to the surface area it is acting.

$\sigma_{\mathrm{c}}=\frac{\text { Load }}{\text { Area }}=\frac{L}{A}$

Where: $\mathrm{L}=$ load, $\mathrm{A}=$ area.

Thermal conductivity is the ability of a material to conduct or transfer heat.

The thermal conductivity of a material is expressed by the formula,

$\mathrm{Q}=\frac{K L}{A \Delta T}$

Where:

$\mathrm{Q}$ is the thermal conductivity $\mathrm{W} / \mathrm{mK}$

$\mathrm{K}$ is the amount of heat transferred through the material in Joules/second or Watts

$\mathrm{L}$ is the distance between the two isothermal planes

$A$ is the area of surface in square metres

$\Delta T$ is the temperature difference between the two isothermal planes

\section{Determination of Hardness}

Hardness is the property of material that enables it to resist plastic deformation, penetration, indentation, scratching or wear. Therefore, hardness is an important property requires in a brake pad to enable it resist wear when the brake is applied.

The test was carried out on Rockwell hardness tester ISO 6508 based on ASTM E18.

\section{Determination of wear}

The test was conducted according to ASTM G99 and DIN 50324. Each of samples was mounted on the Aston Paar pin-on-disk tribometer and run at a velocity of $10 \mathrm{~cm} / \mathrm{s}$ under a load of $8 \mathrm{~N}$ for distance of $50 \mathrm{~m}$. Before running the sample on the equipment, the initial weight $\left(\mathrm{m}_{1}\right)$ of the sample was recorded in $(\mathrm{g})$ 
Gai Peter Friday et al.,; Saudi J Eng Technol, Jan, 2022; 7(1): 16-33

and after running the final weight $\left(\mathrm{m}_{2}\right)$ of the sample was recorded. The difference in weights gives the materials loss of each sample as shown in table7.

Weight lost $=$ Initial weight - Final weight $=m_{1}-m_{2}$.

\section{Determination of Shear Strength}

The shear strength was conducted according to On SM 1000 universal testing machine twenty-seven samples were produce as per the factorial design and were subjected to test. The result of the test is showed in table 7.

Table-7: Results

\begin{tabular}{|c|c|c|c|c|c|c|c|c|c|}
\hline \multirow[t]{2}{*}{ Sample } & \multicolumn{3}{|c|}{$\begin{array}{l}\text { Manufacturing } \\
\text { Parameters }\end{array}$} & \multicolumn{6}{|l|}{ Results } \\
\hline & Mp & Cte & Cti & $\begin{array}{l}\text { Coefficie } \\
\text { nt of } \\
\text { friction }\end{array}$ & $\begin{array}{l}\text { Compressive } \\
\text { strength } \\
\text { (MPa) }\end{array}$ & $\begin{array}{l}\text { Thermal } \\
\text { conductivity } \\
\text { (W/mK) }\end{array}$ & $\begin{array}{l}\text { Hardness } \\
\text { (RHB) }\end{array}$ & $\begin{array}{l}\begin{array}{l}\text { Wear } \\
\text { mass loss } \\
(\mathrm{g})\end{array} \\
\end{array}$ & $\begin{array}{l}\text { Shear } \\
\text { strength } \\
\text { (MPa) }\end{array}$ \\
\hline 1 & 24 & 220 & 10 & 0.272 & 73 & 0.196 & 47 & 0.0075 & 8.5 \\
\hline 2 & 24 & 200 & 15 & 0.284 & 72 & 0.197 & 47 & 0.0074 & 8.5 \\
\hline 3 & 30 & 220 & 5 & 0.441 & 104 & 0.632 & 65 & 0.0045 & 11.5 \\
\hline 4 & 24 & 220 & 5 & 0.284 & 71 & 0.189 & 46 & 0.0075 & 8.6 \\
\hline 5 & 24 & 180 & 5 & 0.265 & 70 & 0.186 & 45 & 0.0075 & 8.6 \\
\hline 6 & 27 & 180 & 10 & 0.329 & 95 & 0.605 & 62 & 0.0056 & 10.6 \\
\hline 7 & 30 & 200 & 15 & 0.435 & 112 & 0.63 & 67 & 0.0045 & 11.8 \\
\hline 8 & 27 & 180 & 15 & 0.367 & 100 & 0.61 & 62 & 0.0057 & 10.7 \\
\hline 9 & 27 & 220 & 5 & 0.356 & 101 & 0.601 & 60 & 0.0057 & 10.5 \\
\hline 10 & 24 & 200 & 5 & 0.284 & 71 & 0.197 & 46 & 0.0076 & 8.5 \\
\hline 11 & 30 & 220 & 10 & 0.444 & 110 & 0.652 & 67 & 0.0046 & 11.7 \\
\hline 12 & 30 & 180 & 10 & 0.414 & 108 & 0.632 & 64 & 0.0045 & 11.5 \\
\hline 13 & 30 & 180 & 15 & 0.428 & 104 & 0.633 & 65 & 0.0047 & 11.8 \\
\hline 14 & 27 & 200 & 15 & 0.376 & 107 & 0.621 & 62 & 0.0054 & 10.5 \\
\hline 15 & 30 & 220 & 15 & 0.476 & 137 & 0.662 & 70 & 0.0045 & 12 \\
\hline 16 & 24 & 180 & 15 & 0.288 & 72 & 0.185 & 46 & 0.0075 & 8.6 \\
\hline 17 & 24 & 180 & 10 & 0.275 & 73 & 0.185 & 45 & 0.0076 & 8.4 \\
\hline 18 & 24 & 220 & 15 & 0.298 & 75 & 0.197 & 47 & 0.0074 & 8.7 \\
\hline 19 & 27 & 200 & 5 & 0.369 & 98 & 0.62 & 62 & 0.0055 & 10.3 \\
\hline 20 & 27 & 180 & 5 & 0.375 & 94 & 0.624 & 61 & 0.0056 & 10 \\
\hline 21 & 30 & 200 & 5 & 0.443 & 115 & 0.645 & 66 & 0.0045 & 11.4 \\
\hline 22 & 30 & 200 & 10 & 0.435 & 123 & 0.634 & 67 & 0.0046 & 11.6 \\
\hline 23 & 30 & 180 & 5 & 0.413 & 110 & 0.633 & 64 & 0.0047 & 11.5 \\
\hline 24 & 24 & 200 & 10 & 0.267 & 70 & 0.195 & 45 & 0.0076 & 8.3 \\
\hline 25 & 27 & 220 & 10 & 0.375 & 100 & 0.625 & 63 & 0.0055 & 10.7 \\
\hline 26 & 27 & 220 & 15 & 0.388 & 101 & 0.63 & 65 & 0.0054 & 10.8 \\
\hline 27 & 27 & 200 & 10 & 0.376 & 101 & 0.626 & 63 & 0.0055 & 10.7 \\
\hline
\end{tabular}

\section{Percentage Water Absorption}

The essence of this test is to ascertain if the basalt-based brake pad can easily absorb water when driving the car long time in rain or water.

In carrying out the test five samples were produced using $30 \mathrm{MPa}, 27 \mathrm{MPa}$ and $24 \mathrm{MPa}$ compaction pressure and curing temperature and time of $220^{\circ} \mathrm{C}$, $200^{\circ} \mathrm{C}, 180^{\circ} \mathrm{C}$ and 15,10 and 5 minutes respectively five samples were picked considering the fact the moulding pressure play a critical role in the properties of the brake pad. The weight of each sample before soaking in water was recorded $\left(\mathbf{M}_{1}\right)$ and the samples were soaked in water for twenty-four hours afterwards the samples were removed from water cleaned and reweighed $\left(\mathrm{M}_{2}\right)$.

The percentage water absorption is calculated using the formula:

$\%$ Water absorption $=\frac{M 2-M 1}{M 1} X 100$

Where:

$\mathrm{M}_{1}$ is the mass of sample before soaking in water $\mathrm{M}_{2}$ is the mass of sample after sucking for $24 \mathrm{hrs}$. The result obtained from the test is showed 8 . 
Table-8: Result of \%Water Absorption Test

\begin{tabular}{|c|c|c|c|c|c|c|c|}
\hline \multirow[t]{2}{*}{ Sample } & \multicolumn{3}{|c|}{ Manufacturing Parameters } & \multirow{2}{*}{$\begin{array}{l}\text { Initial } \\
\text { weight } \\
\text { (g) M1 }\end{array}$} & \multirow{2}{*}{$\begin{array}{l}\text { Final } \\
\text { weight } \\
\text { (g) M2 }\end{array}$} & \multirow{2}{*}{$\begin{array}{l}\text { Difference } \\
\text { (g) }\end{array}$} & \multirow{2}{*}{$\begin{array}{l}\% \quad \text { Water } \\
\text { absorption }\end{array}$} \\
\hline & $\begin{array}{l}\text { Moulding } \\
\text { pressure } \\
\text { (MPa) }\end{array}$ & $\begin{array}{l}\text { Curing } \\
\text { temperature } \\
{ }^{0} \mathrm{C}\end{array}$ & $\begin{array}{l}\text { Curing } \\
\text { time } \\
\text { (min.) }\end{array}$ & & & & \\
\hline 15 & 30 & 220 & 15 & 148.48 & 149.04 & 0.56 & 0.377 \\
\hline 26 & 27 & 220 & 15 & 153.34 & 154.05 & 0.71 & 0.463 \\
\hline 18 & 24 & 220 & 15 & 158.29 & 159.23 & 0.94 & 0.600 \\
\hline 5 & 24 & 180 & 5 & 156.32 & 157.27 & 0.95 & 0.607 \\
\hline 25 & 27 & 220 & 10 & 154.56 & 155.27 & 0.73 & 0.472 \\
\hline
\end{tabular}

\section{Percentage Oil Absorption}

The essence of this test is to ascertain if the basalt-based brake pad can easily absorb oil in case of oil spill on the brake pad.

In carrying out the test five samples were produced using $30 \mathrm{MPa}, 27 \mathrm{MPa}$ and $24 \mathrm{MPa}$ compaction pressure and curing temperature and time of $220^{\circ} \mathrm{C}$, $200^{\circ} \mathrm{C}, 170^{\circ} \mathrm{C}$ and 15,10 and 5 minutes respectively five samples were pick considering the fact the moulding pressure play a critical role in the properties of the brake pad. The weight of each sample before soaking in oil SAE $15 \mathrm{~W} 40$ was recorded $\left(\mathrm{M}_{1}\right)$ and the samples were soaked in oil for twenty-four hours afterwards the samples were removed from water cleaned and re-weighed $\left(\mathrm{M}_{2}\right)$.

The percentage water absorption is calculated using the equation for water absorption above the result obtained is shown in table 9.

Table-9: Result of \% oil Absorption Test

\begin{tabular}{|c|c|c|c|c|c|c|c|}
\hline \multirow[t]{2}{*}{ Sample } & \multicolumn{3}{|c|}{ Manufacturing Parameters } & \multirow{2}{*}{$\begin{array}{l}\text { Initial } \\
\text { weight } \\
\text { (g) M1 }\end{array}$} & \multirow{2}{*}{$\begin{array}{l}\text { Final } \\
\text { weight } \\
\text { (g) M2 }\end{array}$} & \multirow{2}{*}{$\begin{array}{l}\text { Difference } \\
\text { (g) }\end{array}$} & \multirow{2}{*}{$\begin{array}{l}\text { \% Water } \\
\text { absorption }\end{array}$} \\
\hline & $\begin{array}{l}\text { Moulding } \\
\text { pressure } \\
(\mathrm{MPa})\end{array}$ & $\begin{array}{l}\text { Curing } \\
\text { temperature } \\
{ }^{0} \mathrm{C}\end{array}$ & $\begin{array}{l}\text { Curing } \\
\text { time } \\
\text { (min.) }\end{array}$ & & & & \\
\hline 15 & 30 & 220 & 15 & 148.48 & 148.85 & 0.37 & 0.25 \\
\hline 26 & 27 & 220 & 15 & 153.34 & 153.88 & 0.54 & 0.35 \\
\hline 18 & 24 & 220 & 15 & 158.29 & 159,02 & 0.74 & 0.47 \\
\hline 5 & 24 & 180 & 5 & 156.32 & 157.06 & 0,74 & 0.47 \\
\hline 25 & 27 & 220 & 10 & 154.56 & 155.11 & 0.55 & 0.36 \\
\hline
\end{tabular}

\section{Determination of Density}

Density expresses the mass of body per volume, in determining the density of the basalt brake pad portion of friction part of the brake pad was cut off and the weight weighed on an electronic digital weigh balance M311L the weight was recorded. The piece cut was dropped in volume measuring cylinder containing water initially at $58.00 \mathrm{ml}$, when the piece was dropped into the volume measuring cylinder the volume of water rises to $65.5 \mathrm{ml}$. It therefore means that the volume of the piece is $7.5 \mathrm{ml}$ according to Archimedes principle. These records are tabulated in table 10. Three samples were taken since most properties of the basalt brake pad are influenced by mould pressure, for this reason high, medium and low moulding pressure samples were picked, and their density determined. These pressures are 30,27 and $24 \mathrm{MPa}$.

density $(\rho)=\frac{\text { Mass of sample }}{\text { Volume of sample }}$

Table-10: Experimental Density of Basalt Brake Pad at different Manufacturing Parameters

\begin{tabular}{|l|l|l|l|l|l|}
\hline sample & $\begin{array}{l}\text { weight of } \\
\text { sample(g) }\end{array}$ & $\begin{array}{l}\text { volume of } \\
\text { water(m) }\end{array}$ & $\begin{array}{l}\text { volume of water }+ \\
\text { sample }(\mathbf{m l})\end{array}$ & $\begin{array}{l}\text { volume of } \\
\text { sample }(\mathbf{m l})\end{array}$ & $\begin{array}{l}\text { Density } \\
\left(\mathbf{k g} / \mathbf{m}^{\mathbf{3}}\right)\end{array}$ \\
\hline 15 & 20.86 & 58.00 & 65.50 & 7.50 & $2,781.33$ \\
\hline 26 & 20.74 & 58.00 & 66.00 & 8.00 & $2,592.50$ \\
\hline 18 & 20.73 & 58.00 & 66.60 & 8.70 & $2,382.76$ \\
\hline
\end{tabular}

\section{Void content}

\section{Determination of Void Content}

Void is a pore that remains unfilled with polymer in a composite material. Voids are typically the result of poor manufacturing of the material and are generally deemed undesirable. Voids can affect the mechanical properties and lifespan of composites. They degrade mainly the matrix dominated properties such as the interlaminar shear strength, longitudinal 
Gai Peter Friday et al.,; Saudi J Eng Technol, Jan, 2022; 7(1): 16-33

compressive strength and transverse tensile strength (Mehdikhani, et al., 2018). Void can act as crack initiation sites as well as allow moisture to penetrate the composite and contribute to the anisotropy of the composite (Mehdikhani, et al., 2018 \& Hull and Clyne, 1996). The acceptable void content of $1 \%$ is allowed in composite material. An increase void content of 1-3\% can decrease the mechanical properties by $20 \%$ (Lacovara, 2013).

The content in composite materials $\left(\mathrm{V}_{\mathrm{co}}\right)=\frac{\rho t-\rho e}{\rho t}$
$\%$ void content $=\frac{\rho t-\rho e}{\rho t} \times 100$

Where:

$\rho t=$ theoritical density

$\rho e=$ experimental density

The theoretical density of composite material is given by:

$\rho_{\mathrm{t}}=\rho_{\mathrm{m}} v_{\mathrm{m}}+\rho_{\mathrm{f}} v_{\mathrm{f}}$

for the basalt brake pad

$\rho_{\mathrm{t}}=\rho_{\mathrm{b}} v_{\mathrm{b}}+\rho_{\mathrm{c}} v_{\mathrm{c}}+\rho_{\mathrm{br}} v_{\mathrm{br}}+\rho_{\mathrm{f}} \mathrm{v}_{\mathrm{f}}+\rho_{\mathrm{p}} v_{\mathrm{p}}$

$\rho_{\mathrm{t}}=2201 \times 0.38+5281.8 \times 0.26+6266.6 \times 0.12+$ $2670 \times 0.12+1240 \times 0.12=3430.84 \mathrm{~kg} / \mathrm{m}^{3}$

Therefore:

$$
\begin{aligned}
& \% \text { void content @ } 30 \mathrm{mPa}=\frac{(3430.84-2781.33)}{3430.84} \times 100=18.93 \% \\
& \% \text { void content @ } 27 \mathrm{mPa}=\frac{(3430.84-2,592.50)}{3430.84} \times 100=24.43 \% \\
& \% \text { void content @ } 24 \mathrm{mPa}=\frac{(3430.84-2,382.76)}{3430.84} \times 100=30.54 \%
\end{aligned}
$$

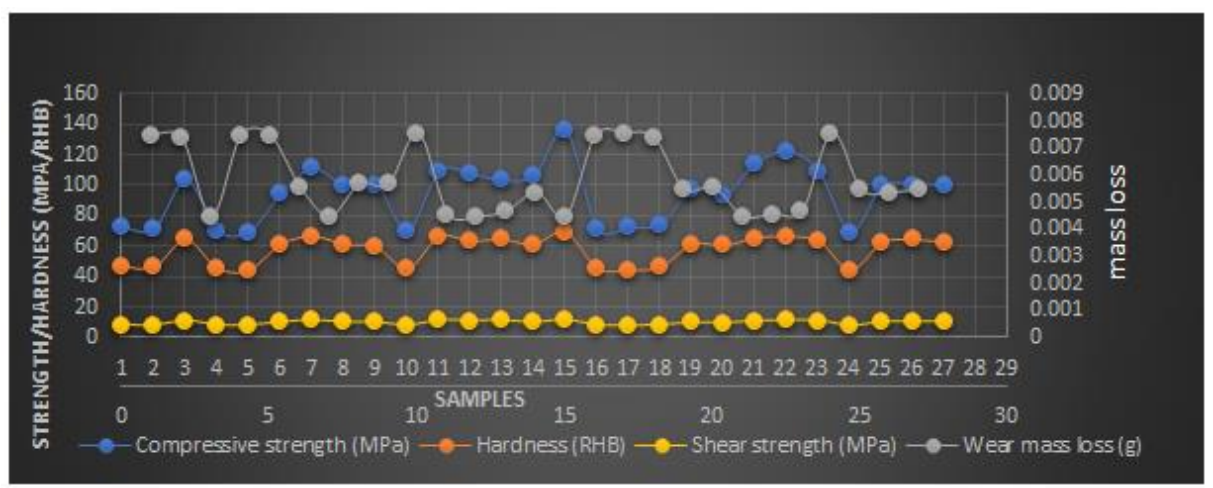

Fig-1: Graph of hardness, wear, compressive and shear strengths

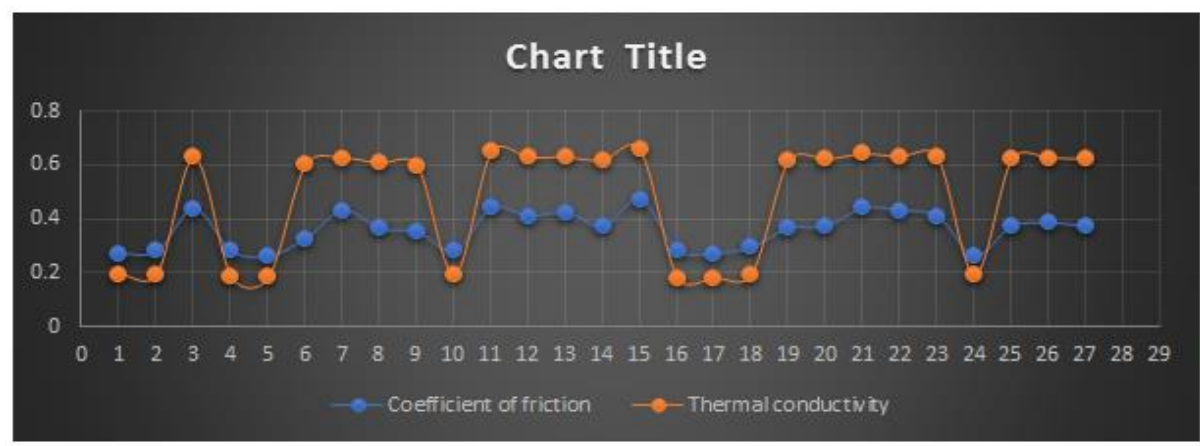

Fig-2: Graph of coefficient of friction and thermal conductivity

\section{Thermal Analysis (TGA)}

The thermal analysis was conducted to know the thermal stability of the basalt brake pad; the TGA was conducted in Federal University Minna using PerkinElmer TGA 4000. The sample of the brake pad with weight 14.933 grams was placed on a pan inside the furnace of the TGA analyzer which is supported by a stem connected to a balance which weigh the material as heating is progressing. The heating temperature was set from $30^{\circ} \mathrm{C}$ to $900^{\circ} \mathrm{C}$ at $10^{\circ} \mathrm{C} / \mathrm{min}$. in a nitrogen atmosphere with a purge rate of $20 \mathrm{ml} / \mathrm{min}$. this was done so that the sample only reacts to temperature. The change in mass of the sample over temperature was recorded through the PC and it was displayed.

\section{DISCUSSION OF RESULTS Coefficient of Friction}


Gai Peter Friday et al.,; Saudi J Eng Technol, Jan, 2022; 7(1): 16-33

The coefficient of friction of the twenty-seven samples ranges between 0.23 to 0.476 the highest coefficient of friction of 0.476 was obtained under $\left(15 \mathrm{mins}\right.$ curing time, $220^{\circ} \mathrm{C}$ curing temperature and $30 \mathrm{MPa}$ moulding pressure) manufacturing parameters as shown in table 7.

The value is same with value obtained in the solution of the objective function of the optimization model this validates the model. The value of 0.476 is within the range of 0.3-0.6 as stated by (Anderson 1980) but less than the value of ceramic matrix brake pad 0.56 (Sekunowo et al., 2020). However, the value is higher than of asbestos and palm kernel shell brake pad which has 0.4 and 4.4 respectively (Ibhadode and Dagwa, 2008).

The Pareto chart obtained from the (DoE) of minitab software in fig. 3 showed the influence of the manufacturing parameters on the coefficient of friction where moulding pressure Mp has more effect than other parameters. The interaction of the parameters has no effects on the coefficient of friction.

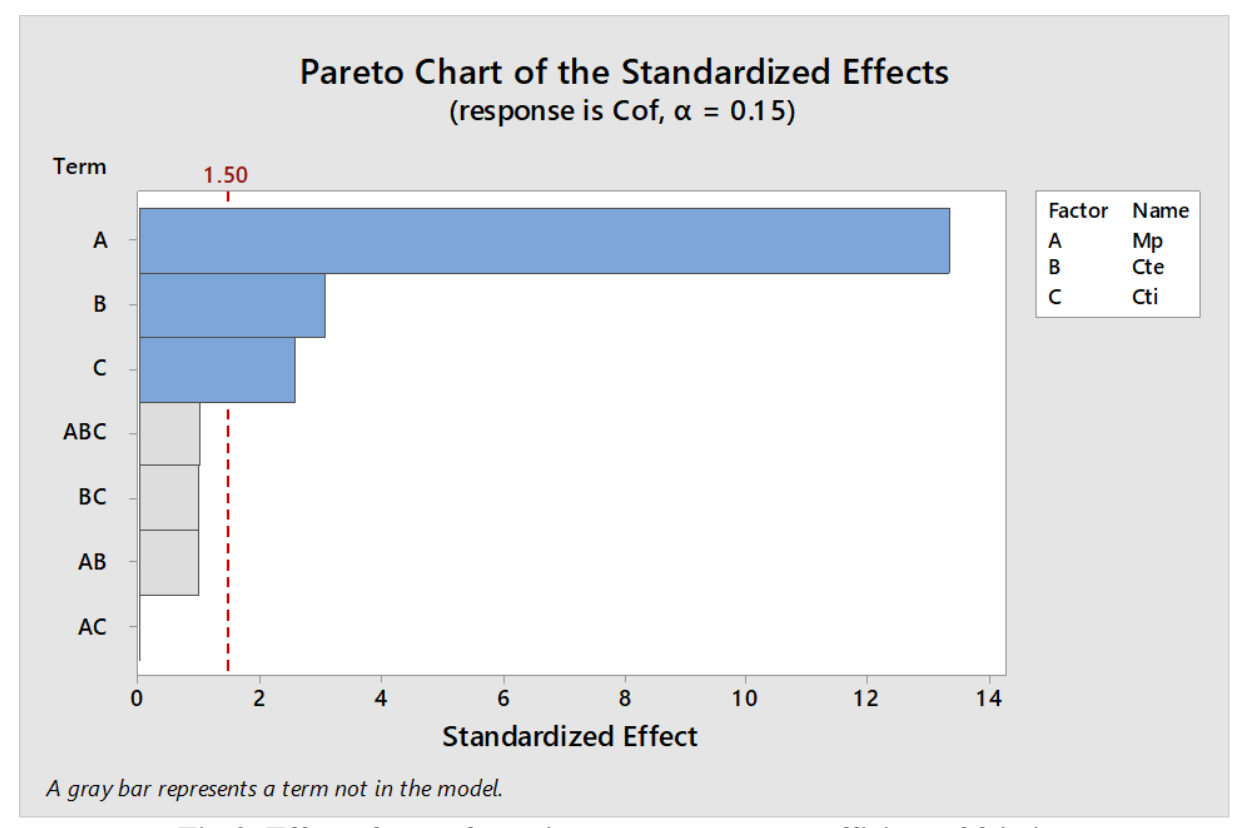

Fig-3: Effect of manufacturing parameters on coefficient of friction

\section{Compressive Strength}

The compressive strength of the basalt-based brake pad ranges from $70-137 \mathrm{MPa}$. The highest value shown in table 7 is $137 \mathrm{MPa}$ obtain under set of manufacturing parameters of $30 \mathrm{MPa}$ moulding pressure, $220^{\circ} \mathrm{C}$ curing temperature and $15 \mathrm{~min}$. curing time. This value is higher than the value of the compressive strength of asbestos brake pad which is $110 \mathrm{MPa}$ and higher than the value palm kernel shell brake pad and the quoted value in literature which range between 70-125MPa. (Ibhadode and Dagwa, 2008), but less than that of Ceramics brake pad which is 141$156 \mathrm{MPa}$ (Sekunowo et al., 2020).

It therefore means the compressive strength under this set of manufacturing parameters can safely be used. Although it is not equal to the value obtained in the solution of the optimization model this is due to high void content in the basalt-based brake pad and this collaborate the point stated by (Mehdikhan, et al. 2018) on the effect of void content on the mechanical properties of brake pad this void could be as a result of the materials spring back when the moulding pressure has been released.

The compressive strength under the manufacturing parameters of $27 \mathrm{MPa}$ moulding pressure, $220^{\circ} \mathrm{C}$ curing temperature and 15 minutes curing time is $101 \mathrm{MPa}$ this value is slightly less than the value of the commercial brake pad and the palm kernel brake pad, but it is within the range of the quoted value in literature.

For manufacturing parameters of $24 \mathrm{MPa}$ moulding pressure, $220^{\circ} \mathrm{C}$ curing temperature and 15 minutes curing time the value of the compressive strength is $70 \mathrm{MPa}$, this value is less than that of commercial brake pad and palm kernel brake pad, but it is the minimum value in the range of the literature quoted values.

The Pareto chart fig.4 showed that only moulding pressure has influence on the compressive strength. 


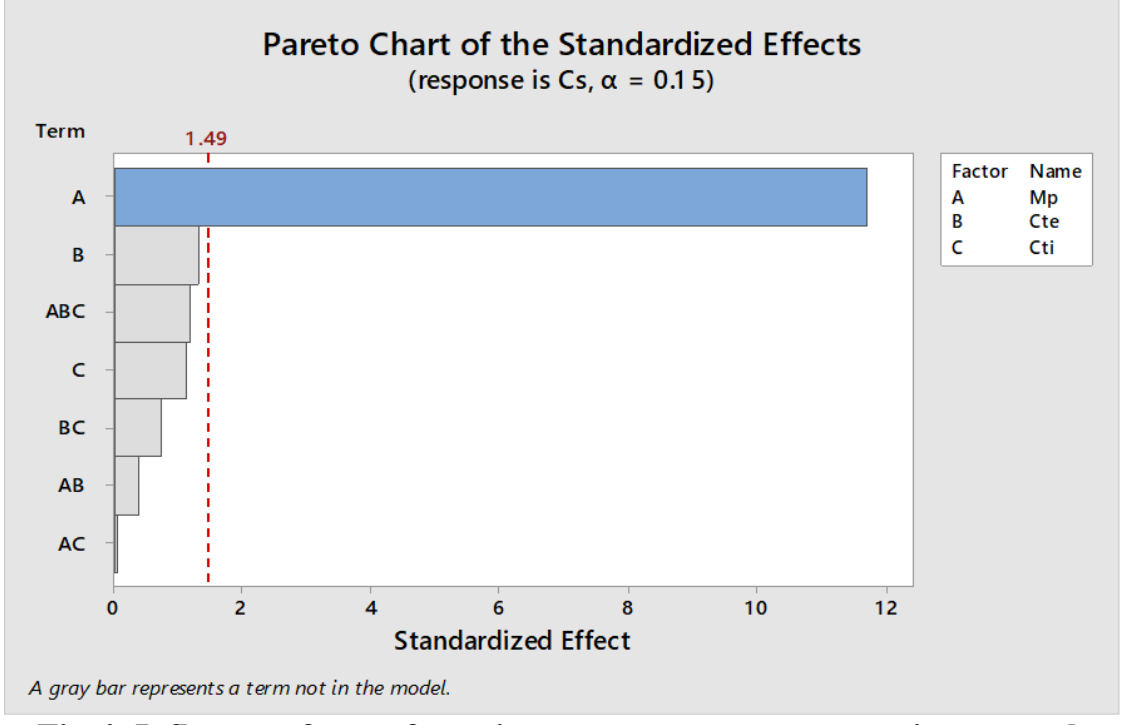

Fig-4: Influnece of manufacturing parameters on compressive strength

\section{Thermal Conductivity}

The highest thermal conductivity of the Basaltbased brake pad is $0.663 \mathrm{~W} / \mathrm{mK}$ this falls under the manufacturing parameters of $30 \mathrm{MPa}$ moulding pressure, $220^{\circ} \mathrm{C}$ curing temperature and 15 minutes curing time as shown in table 7, this value is less than the value of palm kernel brake pad which is $1.4 \mathrm{~W} / \mathrm{mK}$ (Dagwa, et al. 2008) but higher than that of ceramic matrix brake pad which has a value of $0.539 \mathrm{~W} / \mathrm{mK}$ (Sekunowo et al. 2020) and within the range of literature quoted value $0.47-0.804 \mathrm{~W} / \mathrm{mK}$ (Ibhadode and Dagwa, 2008).

Under the manufacturing parameters $27 \mathrm{MPa}$ moulding, $220^{\circ} \mathrm{C}$ curing temperature and 15 minutes curing time the value is $0.630 \mathrm{~W} / \mathrm{mK}$ this value is higher than the value of thermal conductivity of ceramics brake pad and fall within the range of the quoted values in literature.

The lowest thermal conductivity is $0.197 \mathrm{~W} / \mathrm{mK}$ which is under the set of $24 \mathrm{MPa}$ moulding pressure, $220^{\circ} \mathrm{C}$ curing temperature and 15 minutes curing time this value far less than the values in quoted literature and commercial brake pad.

Therefore, it can be inferred that, the first two sets of manufacturing parameters are suitable for the manufacturing of basalt-based brake pad.

From the table 7 of one can clearly see that the moulding pressure has greater influence on the thermal conductivity of the basalt-based brake pad this is possible because the higher moulding pressure the minimum the void in the brake pad and this can result to close contact of the materials particles consequently improving the thermal conductivity. If there are more voids within the brake pad the air entrapped between the particles of the brake pad will hinder thermal conduction because air is a poor conductor of heat.

The Pareto chart fig.6 showed that the moulding pressure has more influence followed by the interaction between the curing temperature and time and the least is the curing time.

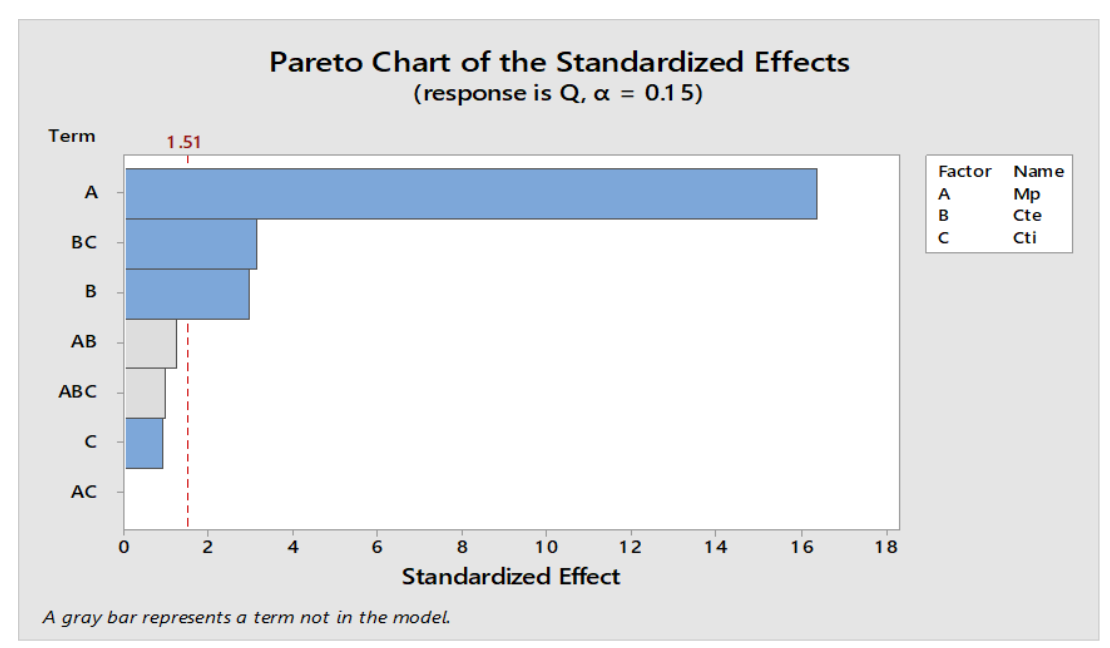

Fig-6: Influence of manufacturing parameters on thermal conductivity 


\section{Hardness}

Sample 15 of the basalt-based brake pad has the highest hardness of 70RHB obtained under manufacturing parameters of $30 \mathrm{MPa}$ moulding pressure, $220^{\circ} \mathrm{C}$ curing temperature and 15 minutes curing time. The minimum hardness is $45 \mathrm{RHB}$ under manufacturing parameters of $24 \mathrm{MPa}, 180^{\circ} \mathrm{C}$ curing temperature and 5 minutes curing time as shown in table 11.

The 70RHB is (equivalent to 121 in Brinell hardness $3000 \mathrm{kgf}$ ) this value is higher than that of asbestos brake pad and Palm kernel shell brake pads which has Brinell hardness 101 and 92 respectively.
It is observed that the moulding pressure has much influence on the hardness of the basalt-based brake pad more than others manufacturing parameters. It is also noticed that the hardness increases with increase in moulding pressure this is supported by the work of (Taiwo et al. 2019) on the effect of moulding pressure on the mechanical properties of brake pad. They noted that it is important to reduce the porosity to the minimum by proper compaction of the mixture in other to eliminate voids.

The pareto chart fig. 7 showed that the moulding pressure has more effect on the hardness while curing time and temperature have less effects while the interaction of curing time and temperature have least effect.

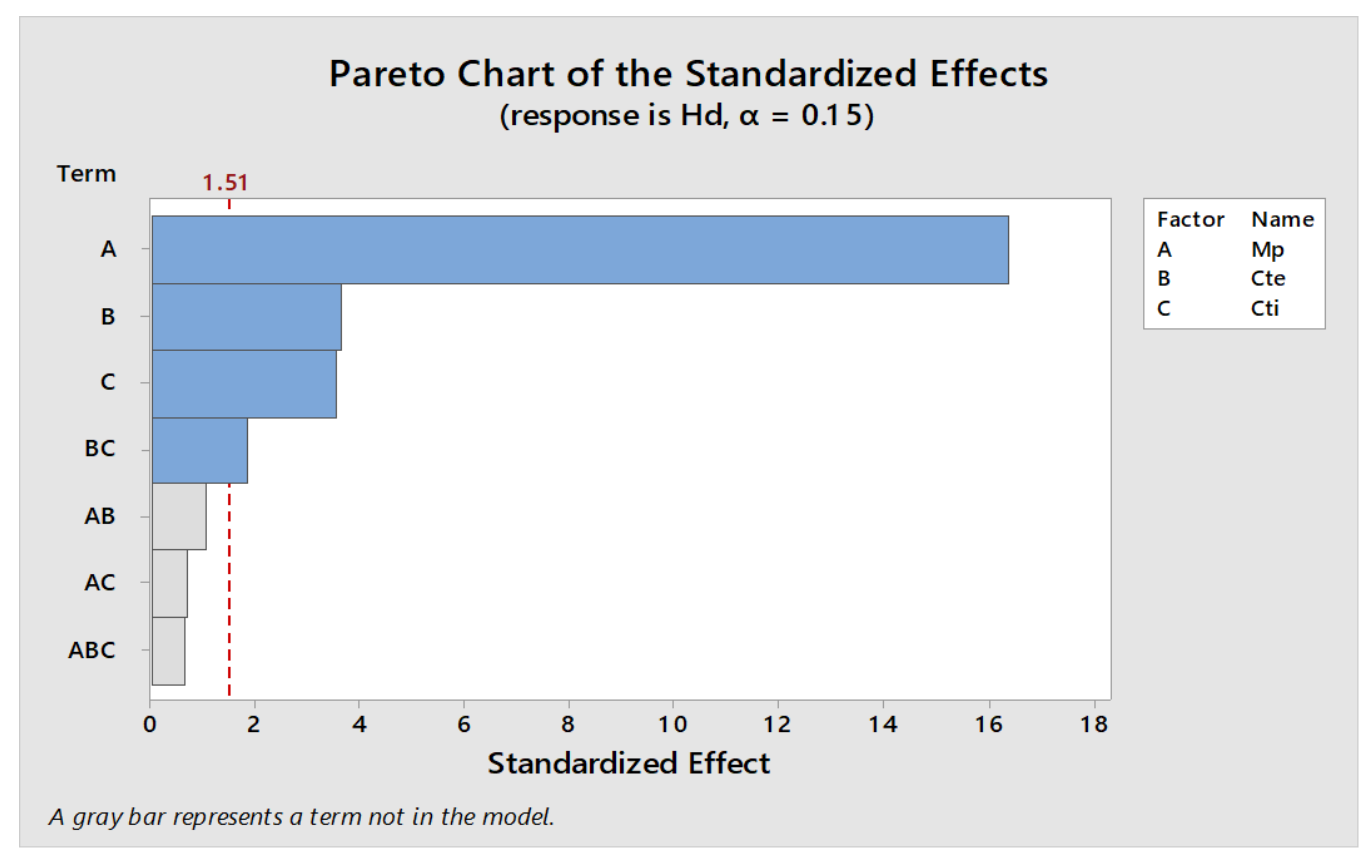

Fig-7: Influence of manufacturing parameters of hardness

\section{Wear Rate}

The wear rate indicates the amount of material removed under application of sliding load over a surface of the material. Increasing the moulding pressure decreases the wear rate because the higher the moulding pressure the closer materials particles are highly packed, and the bonding of the material become better and wear rate become less.

Other manufacturing parameter like temperature and curing time has less influence on the wear rate of the brake pad as shown in table 7.
Fig. 8 the Pareto chart showed that the curing time does not have influence on the wear rate, but moulding pressure has the highest influence.

The manufacturing parameters of $30 \mathrm{MPa}$ moulding pressure gives a better wear rate of $0.0045 \mathrm{~g}$ which is $4.5 \mathrm{mg}$, this value is slightly higher than standard wear of $3.0 \mathrm{mg}$ according to (Bush et al., 1972). 


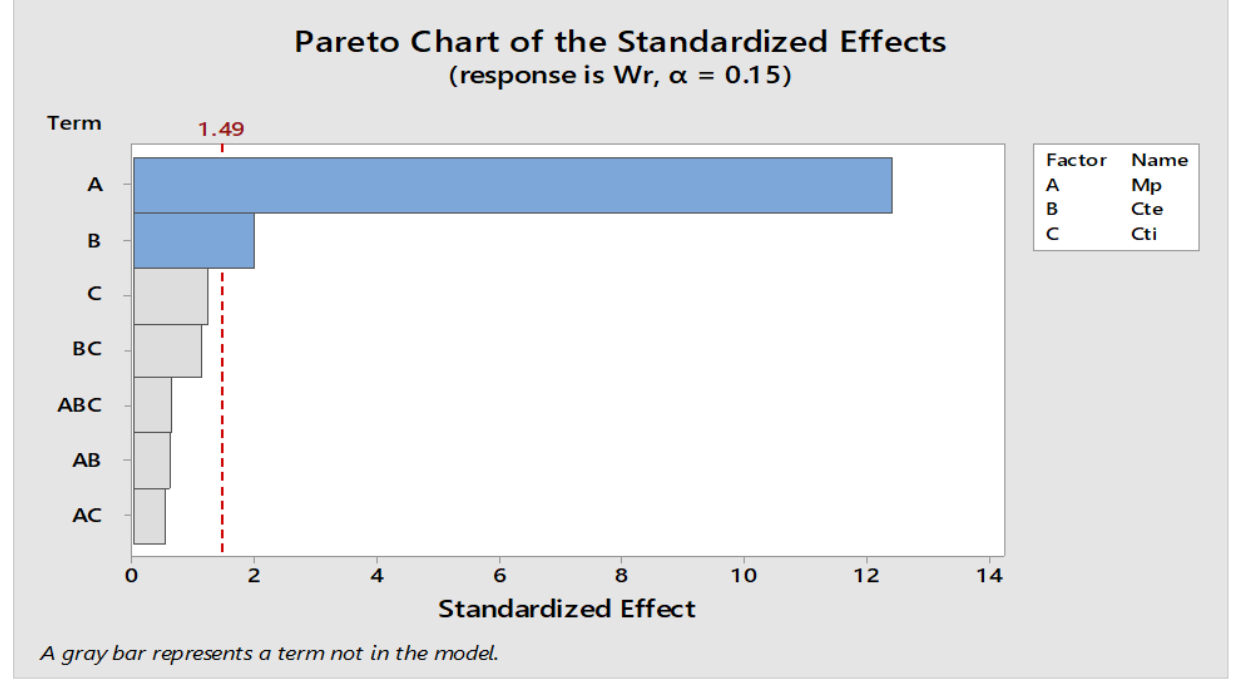

Fig-8: Influence of manufacturing parameters on wear

\section{Shear Strength of Basalt-based Brake Pad}

The shear strength of the basalt-based brake pad ranges from 8.3 to $12 \mathrm{MPa}$ where the best manufacturing parameters are $30 \mathrm{MPa}$ moulding pressure, $220^{\circ} \mathrm{C}$ curing temperature and 15 minutes curing time. The value is higher than that of ceramics brake pad which is $5.47 \mathrm{MPa}$ (Sekunowo et al., 2020).
Asbestos and Palm kernel brake pad has 5.46MPa and 2.45MPa respectively (Ibhadode and Dagwa, 2008).

The Pareto chart fig. 9 showed that the moulding pressure has more influence than other manufacturing parameters. The higher the moulding pressure the more the bonding of the materials and the less the pores which act as point of failure of the brake pad when subjected shear force.

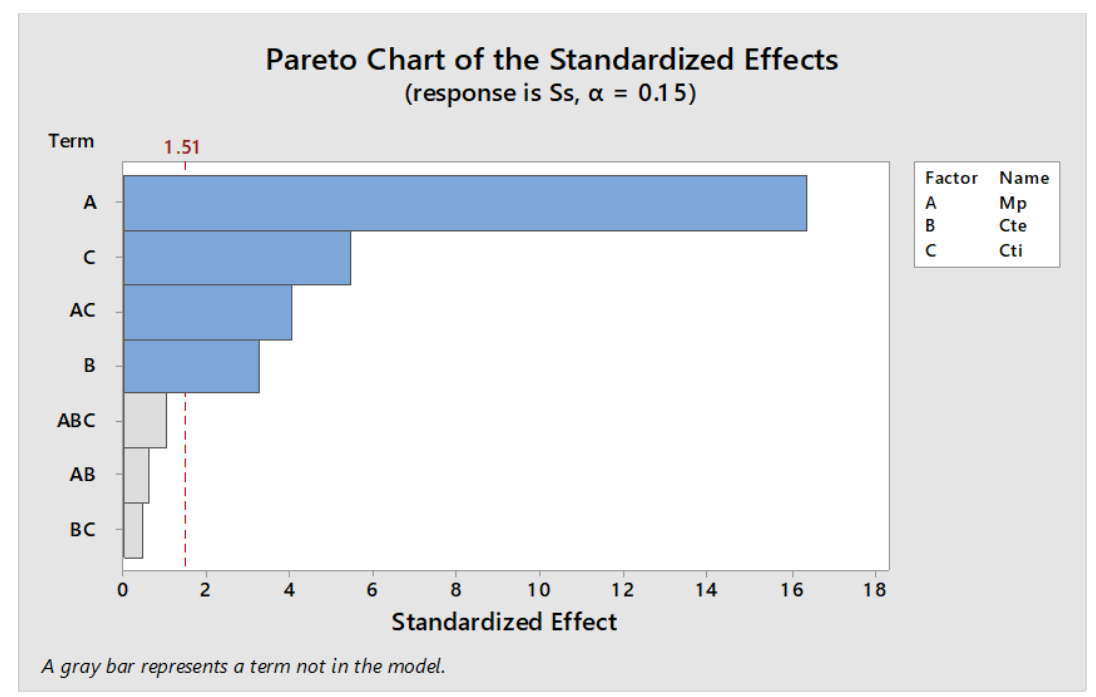

Fig-9: Influence of manufacturing parameters on shaer strength

\section{Water Absorption of Basalt-based Brake Pad}

The water absorption of the basalt-based brake pad is inversely proportional to the moulding pressure that is, as the moulding pressure is increase the water absorption of the basalt brake pad reduced and vice versa. This is so because when the moulding pressure is high the pores or space between the particles of the constituent materials are collapsed and the particles closely packed. These pores which would have served as storage spaces for water when the pad is submerged in water are reduced so the pad water absorption is low unlike when the moulding pressure is low. The best water absorption for this designed is $0.377 \%$ for manufacturing parameters of $30 \mathrm{Mpa}$ moulding pressure, $220^{\circ} \mathrm{C}$ curing temperature and 15 minutes curing time this value is within the range of ceramics brake pad which 0.3-0.4 (Sekunowo et al., 2020) as shown in table 8 .

\section{Oil Absorption of Basalt-based Brake Pad}

The oil absorption of the basalt-based brake pad decreases with increase in moulding pressure and vice versa. This is so because when the moulding pressure is high the pores or space between the particles 
of the constituent materials are collapsed and the particles are closely packed. These pores would have served as storage spaces for oil when the pad is submerged in oil are reduced so the pad oil absorption is low unlike when the moulding pressure is low. The best oil absorption for this designed is $0.25 \%$ for manufacturing parameters of 30Mpa moulding pressure, $220^{\circ} \mathrm{C}$ curing temperature and 15 minutes curing time as shown in table 9 .

\section{Density of Basalt-based Brake Pad}

It is observed that the density of the basaltbased brake pad increase with increase in moulding pressure. The reason being that as the moulding pressure increase the particles of the constituent materials are packed more closely thereby reducing the reducing the volume of the pad by eliminating the pores in between the particles but the mass remained unchanged.

Since density is a function of mass divided by volume and because volume been the denominator is reduced because of the moulding pressure and mass been the numerator remain unchanged then the value of the density increases as shown in table 10 .

This finding confirmed the work of (Taiwo, et al., 2019) on the effect of moulding pressure on brake lining produced from industrial waste. The curing temperature and time does not have much influence on the density.
High void content can affect the strength of the composite material. The minimum void content of the basalt-based brake pad is $18.93 \%$ under manufacturing parameter of $30 \mathrm{mPa}$ moulding pressure the value is within value quoted in literature 13-23\% (Ibhadode and Dagwa, 2008). This value could be lower if not of spring back of materials when the moulding pressure was released, and this affected the compressive strength and thermal conductivity which could be the reason why the values are lower than value obtained in the solution of optimization model of volume fraction.

Although void content has disadvantage it also has advantage in brake pad the natural frequency of brake pad when in contact with rotating disc continuously decrease with increase in porosity or void thereby reducing the noise of the brake when it is applied (Meechai, et al., 2018). This implies that brake pad will not be noising when applied.

\section{Thermal Analysis of Basalt-based Brake Pad}

In figure 10 The TGA curve shows three steps of weight loss; the first is from $30^{\circ} \mathrm{C}$ to $300^{\circ} \mathrm{C}$ weight lost as a result of moisture, from $300^{\circ} \mathrm{C}$ to $530^{\circ} \mathrm{C}$ as a result of further removal of moisture and volatile materials and from $530^{\circ} \mathrm{C}$ to $828^{\circ} \mathrm{C}$ as a result of pyrolysis.

The DTA curve shows that the highest mass decomposition of the sample occurs at $600^{\circ} \mathrm{C}$. This value is higher than that of asbestos which is stable $500^{\circ} \mathrm{C}$ (Nicholson, 1995).

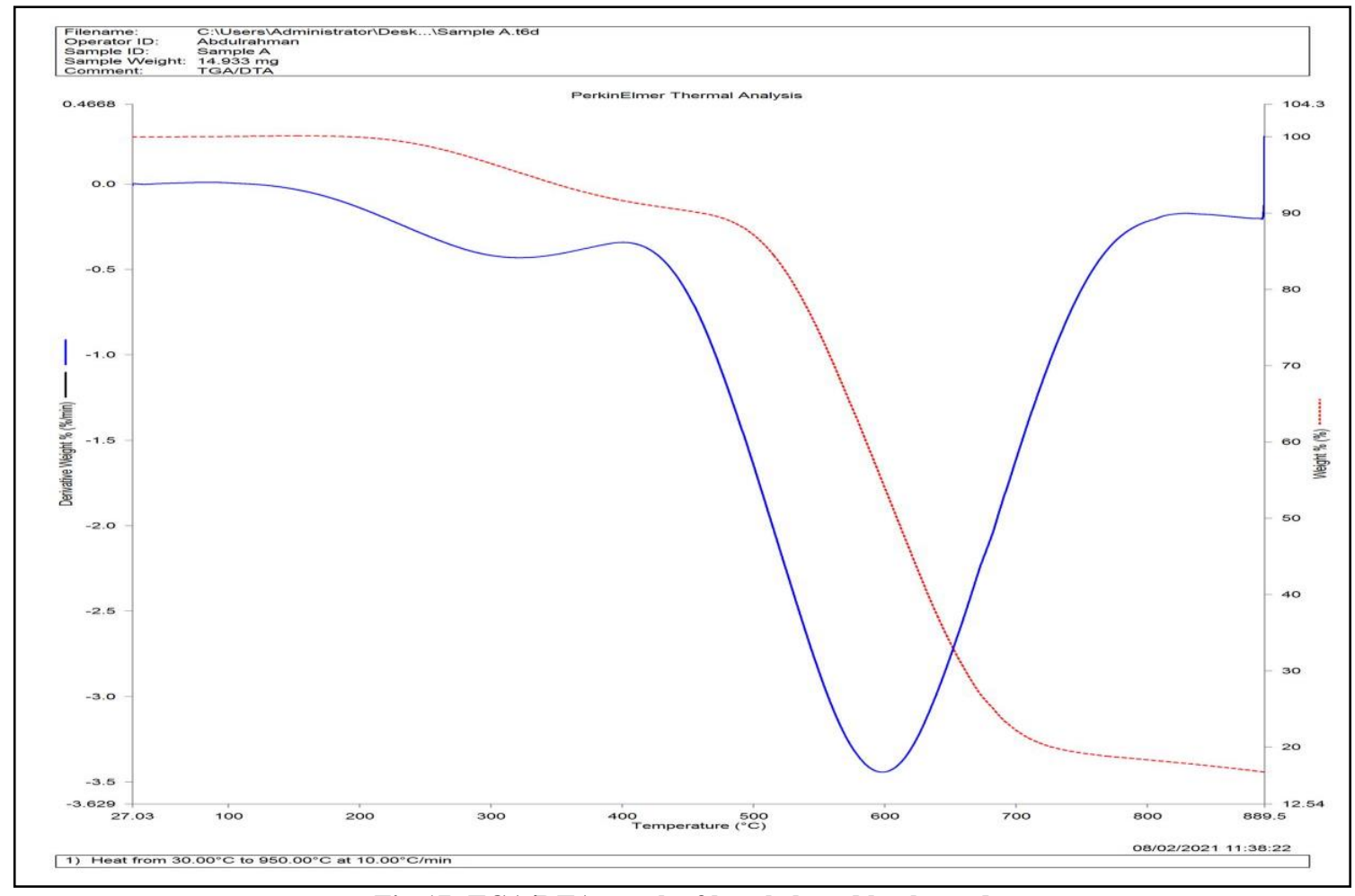

Fig-17: TGA/DTA graph of basalt-based brake pad 
Gai Peter Friday et al.,; Saudi J Eng Technol, Jan, 2022; 7(1): 16-33

\section{CONCLUSION}

It is obvious the physical and mechanical properties of the basalt-based brake pad are good when compared to ceramics brake pad and they are better than other materials used in manufacturing of brake pad. Although the compressive strength, coefficient of friction and lower than that of ceramics brake pad but the are within the range of literatures values. The thermal conductivity and shear strength of the basaltbased brake pad are better than that of ceramics brake pad. Therefore, one can infer that basalt-based brake pad can comfortably serve as a substitute to ceramic brake pad.

\section{ACKNOWLEDGEMENT}

We want to acknowledge the Federal University of Minna for conducting the TGA test for us and the Nigeria Institute of Geoscience Tudun wada Jos for conducting the elemental composition of the basalt material. Final we appreciate the Management of Abubakar Tafawa Balewa University for give us the labs and workshop to produce the brake pad.

\section{REFERENCES}

- Adegbola, J. O., Adedayo, S. M., Ohijeagbon, I. O. (2017). Development of Cow Bone Resin Composites as A Friction Material for Automobile Braking Systems. Journal of Production Engineering. PE. 20(1).

- Adeyemi, I.O., Ademoh, N.A., Okwu, M.O. (2016). Development and Assessment of Composite Brake Pad Using Pulverized Cocoa Beans Shell Filler. International Journal Materials Science and Application (2016) 5 (2) pg 66-78.

- Adeyemi, I.O., Nuhu, A.A., Thankgod, E.B. (2016). Development of Asbestos-Free Automotive Brake Pad Using Ternary Agro-Waste Filler. Journal of Multidisciplinary Engineering Science and Teechnology (JMEST) 2016.

- Aigbodion, V. S., Agunsoye, J. O., Hassan, S. B., Asuke, F., \&Akadike, U. (2010). Development of Asbestos-free Brake pad using Bagasse: Tribology in industry, 32(1).

- Cho, M., Kim, D., \& Kim S. J. (2005). Effects of ingredients on tribological characteristics of a brake pad, an experimental case study, Wear, 258(11-12): 1682-1687.

- Durowaye, S., Sekunowo, O., \& Lawal, G. Physical and mechanical characterisation of asbestos-free particulate ceramic matrix composites. Eskişehir Technical University Journal of Science and Technology A-Applied Sciences and Engineering, 21(4), 562-574.

- Elakhame, Z. U., Alhassan, O. A., \& Samuel, A. E. (2014). Development and production of brake pads from palm kernel shell composites. International Journal of Scientific \& Engineering Research, 5(10), 735-744.
- Ibhadode, A. O. A., \& Dagwa, I. M. (2008). Development of asbestos-free friction lining material from palm kernel shell. Journal of the Brazilian Society of Mechanical Sciences and Engineering, 30(2), 166-173.

- Idris, U. D., Aigbodion, V. S., Abubakar, I. J., \& Nwoye, C. I. (2015). Eco-friendly asbestos free brake-pad: Using banana peels. Journal of King Saud University-Engineering Sciences, 27(2), 185192.

- $\quad$ Ikpambese, K.K., Gundu D.T., Tuleun L.T. (2014). Evaluation of palm Kernel Fibre for Production of Asbestos-Free Automotive Brake Pads. Journal of King Saud University Engineering Science (2016) 28 Feb. pg 110-118.

- Kim, S. J., Kim, K. S., \& Jang, H. (2003). Optimization of manufacturing parameters for a brake lining using Taguchi method. Journal of Materials Processing Technology, 136(1-3), 202208.

- Krenkel, W., \& Langhaf, N. (2014). Ceramics Matrix Composite for High Performance Friction Performance. Proceedings of IV Advanced Ceramics and Application. Conference: 2014 Sept. 29-Oct $1^{\text {st }}$. Belgrade, Serbia.

- Made from Rice Husk and Palm Kernel Shell Powder. International Journal of Agriculture and Bioscience.

- McDonald, A. D., Harper, A., El Attar, O. A., \& McDonald, J. C. (1970). Epidemiology of primary malignant mesothelial tumors in Canada. Cancer, 26(4), 914-919.

- Mutlu, I., Eidogan, O., Findik, F. (2005). Production of ceramic additive automotive brake pad and investigation of its braking characteristics, International Journal of Tribology, 84-92

- Mutlu, I., IIker, S., Ahmet, K. (2015). The Effect of Porosity in Friction Performance of Brake Pad Using Waste Tire Dust. Polimeros, 25(5) 440-446 (2015)

- Ngigbo, S.C., \& Asogwa, I.O. (2016). Production and performance Evaluation of Brake Pad

- Nicholson, G. (1995). Facts about Friction, P\&W Price Enterprises, Inc., Croydon, PA.

- Pai, A., Subramanian, S., \& Sood, T. (2020). Tribological response of waste tire rubber as microfillers in automotive brake lining materials. Friction, 8(6), 1153-1168.

- Ruzaidi, C.M., Mustafa, A. B., Shamsul, J.B., \&Alida A., \&Kamarudin, H. (2011). Morphology and Wear Properties of Palm Ash and PCB Waste Brake Pad., International Conference on Asia Agriculture and Animal IPCBEE vol.1, IACSIT Press, Singapore.

- Sai Balaji, M.A., \& Kalaichelvan, K. (2012). Optimization of Non -Asbestos Semi-Metallic Disc Brake Pad Formulation with Respect to Wear and Friction. Procedia Engineering, 38(2012) pg 16501657. 
- $\quad$ Stanton, M. F., \& Wrench, C. (1972). Mechanisms of mesothelioma induction with asbestos and fibrous glass. Journal of the National Cancer Institute, 48(3), 797-821.

- Taiwo, O.O., Joseph, S.T., Adeyinka, A., Gbenga, A.J. (2019). Effect of Moulding Pressure on Brake Lining Produced from Industrial waste Material: Saw Dust. European Journal of Engineering Research and Science, 4(6), June (2019).

- Talib, R. J., Mohmad, S. S., Ramlan, K. (2012). Selection of best formulation for semi-metallic brake friction materials development. Powder metallurgy (accessed at www.intechopen.com), 130.

- Todorovic, J. (1987). Modelling of the tribological properties of friction materials used in motor vehicles brakes. Processing Instn. Mechanical Engineers, 226, 911-916.

- Zaharudin, A., Talib, R., Barhan, M., Budin, S., \& Aziurah, M. (2012). Investigation of Manufacturing Parameters on the Physical and Tribological Properties of Friction Materials. International Journal of Mechanical and Materials Engineering, 8(2012), 83-88. 